\title{
Organic No-Till with Roller Crimpers: Agro-Ecosystem Services and Applications in Organic Mediterranean Vegetable Productions
}

\author{
Stefano Canali ${ }^{1}$, Mariangela Diacono ${ }^{2}$, Gabriele Campanelli ${ }^{4} \&$ Francesco Montemurro ${ }^{3}$ \\ ${ }^{1}$ Consiglio per la Ricerca e l'analisi dell'economia Agraria, CRA-RPS, Research Centre for the Soil-Plant System, \\ Roma, Italy \\ ${ }^{2}$ Consiglio per la Ricerca e l'analisi dell'economia Agraria, CRA-SCA, Research Unit for Cropping Systems in \\ Dry Environments, Bari, Italy \\ ${ }^{3}$ Consiglio per la Ricerca e l'analisi dell'economia Agraria, CRA-SCA, Research Unit for Cropping Systems in \\ Dry Environments (Azienda Sperimentale Metaponto - ASM), Italy \\ ${ }^{4}$ Consiglio per la Ricerca e l'analisi dell'economia Agraria, CRA-ORA, Research Unit for Vegetable Crops, \\ Monsampolo del Tronto (AP), Italy \\ Correspondence: Stefano Canali, CRA-RPS, Research Centre for the Soil-Plant System, Roma, Italy. Tel: \\ 39-06-700-5413 ext. 242. E-mail: stefano.canali@entecra.it
}

Received: February 8, 2015 Accepted: April 6, 2015 Online Published: June 20, 2015

doi:10.5539/sar.v4n3p70 URL: http://dx.doi.org/10.5539/sar.v4n3p70

\begin{abstract}
In sustainable/organic farming systems, Agro-ecological Service Crops (ASC) may provide many beneficial ecosystem services, when they are introduced as buffer zones, living mulches or break crops. This outlook paper focuses on: i) the role of ASC genotype and mixtures as catch crops for soil mineral nitrogen $\left(\mathrm{NO}_{3}{ }^{-}\right)$surplus, which is returned to the system after their termination; ii) living mulches and break crops management strategies, particularly comparing ploughing under (green manure) with termination by roller crimper; iii) summary of three recent case studies that have assessed the effectiveness of ASC management by no-till with roller crimper for tomato, zucchini and melon crops, under Mediterranean conditions. Recently, in central Italy yield and quality results on organic tomato indicated that this crop was suitable following termination of leguminous ASC by roller crimping. Similarly, this ASC management increased yield by about $70 \%$ compared to green manure in zucchini crop. In southern Italy, no substantial differences were found in the ASC management and organic fertilizer interactions in organic melon, confirming the suitability of matching these strategies to sustain crop production. More studies should be encouraged to further empower the use of ASC in a wide range of agro-climatic conditions. Furthermore, additional studies on the roller crimper should be performed, mainly to understand the dynamic of $\mathrm{N}$ mineralisation in the soil-mulch interface and synchronisation of $\mathrm{N}$ release with cash crop N requirements. Finally, Decision Supporting Systems (DSS) for ASC introduction into vegetable cropping systems should be developed.
\end{abstract}

Keywords: agro-ecological service crops, break crops, buffer zones, living mulch, termination strategies

\section{Background of the Study}

Various terms have been used to identify crops with multiple agro-environmental functions (i.e. catch crops, cover crops, complementary crops, green manure, etc.). Therefore, the new terminology of Agro-ecological Service Crops is being introduced to overcome the lack of a comprehensive and all-embracing term, to include all crops used in agro-ecosystems to provide or enhance its environmental functions (i.e. as buffer zones, living mulches and break crops), irrespective of their position in the crop rotation and/or independently of the method (green manure $v s$ flattened crop) that can be applied to terminate them. Therefore, ASC are generally not directly aimed at improving crop yield, even if most of the time they indirectly contribute to sustain agricultural production by a wide range of mechanisms (Canali, 2013).

In sustainable/organic farming systems, ASC represent a powerful tool for farmers to positively influence the agro-ecosystem by promoting the whole soil-plant system equilibrium in space and time (Kremen \& Miles, 2012; Canali, 2013; Wezel et al., 2014). ASC may have impact on soil fertility (Thorup Kristensen et al., 2012; Montemurro et al., 2013), occurrence of weeds (Bàrberi, 2002; Hayden et al., 2012), diseases and pests 
(Masiunas, 1998; Patkowska et al., 2013). They increase soil carbon (C) sink potential (Mazzoncini et al., 2011), influence greenhouse gasemission (Sanz-Cobena et al., 2014) and improve system energy use efficiency (Gomiero et al., 2008; Canali et al., 2013). ASC can also greatly reduce leaching of nutrients like soil nitrate $\left(\mathrm{NO}_{3}^{-}\right)$(Kristensen \& Thorup-Kristensen, 2004).

\section{Including ASC in Agro-Ecosystems}

\subsection{Buffer Zones}

The introduction of ASC in agro-ecosystems is achieved by several complementary strategies that should be taken into account when designing the cropping system. Accordingly, ASC can be cultivated as 'ecological compensation areas', in the border of the fields and/or in their immediate surroundings, using the parts or portions of a farm/field that are generally not destined to grow the cash crops (i.e. high slope areas, border of ditches, etc; Marshall \& Moonen, 2002; Tilman et al., 2002). This environmental structure may act as a buffer zone (or strip) and function in water quality improvement. Indded, buffer zones can play a role in reduction of $\mathrm{NO}_{3}{ }^{-}$contamination of surface waters due to runoff from agricultural fields. Also wetland riparian zones have bee identified as effective to reduce the amount of $\mathrm{NO}_{3}{ }^{-}$of agricultural origin which reaches surface waters.

\subsection{Living Mulches and Break Crops}

The ASC can also be introduced in the cropping system as living mulches (LM): ASC is intercropped with a cash crop and maintained as a living ground cover throughout the growth cycle. Living mulched systems are managed in order to make most of the system resources (i.e. water, nutrients, light) available to the harvestable crop. Simultaneously, management of the ASC is optimised to provide its environmental services at field/farm level (i.e. increase nutrient availability, contribute to weed, pest and diseases management, biodiversity conservation, $\mathrm{NO}_{3}{ }^{-}$leaching reduction, etc.) and to reduce competition with the cash crop (Swenson et al., 2004; Vanek, 2005; Bath et al., 2008; Theriault et al., 2009; Canali et al., 2014). However, many attempts to use LM in annual cropping systems have resulted in reduced yields of the cash crops (Hiltbrunner et al., 2007; Chase \& Mbuya, 2008). According to Masiunas (1998) the success of such systems depends on the capacity to rapidly establish a ground cover and smother weeds, without competing for resources with the associated crop.

Vegetables with a high nitrogen $(\mathrm{N})$ demand, such as cauliflower, can cause intensive leaching of $\mathrm{NO}_{3}{ }^{-}$to the environment in conventional as well as in organic production. In organic cropping system, the use of an in-season LM may decrease the risk of $\mathrm{NO}_{3}{ }^{-}$leaching after harvest, when left to grow in the field to the end of the leaching season in spring. It has been recently demonstrated that the continued presence of LM in the field over winter may reduce the soil mineral $\mathrm{N}$ content compared to bare soil after the sole crop during the leaching season and, as a consequence, contribute to lower the $\mathrm{NO}_{3}{ }^{-}$leaching risk from the horticultural systems (Kristensen et al., 2014).

Another option for designing sustainable cropping systems in accordance with agro-environmentally sound criteria, is the use of ASC as break crops. These crops are cultivated as sole crop in the rotation, between two consecutive cash crops. Low input/sustainable and organically managed agro-ecosystems for vegetable production that are widespread in the European environments are often include break ASC in the rotation. In Central and Northern Europe break ASC crops are mainly cultivated in the winter season to avoid direct competition for land with the cash crops, which, conversely, are mainly cultivated during the warm season (Masiunas, 1998). In milder Mediterranean climatic areas (i.e. Southern Europe), vegetable cropping systems are based on rotations in which cash crops are grown either in the warm or in the cold winter seasons. From an economic point of view, these vegetable cropping systems are rather important, since they provide quality products to be consumed locally or exported to the Northern European areas year round. In the Southern European areas, farmers grow ASC in the rainy season, to exploit rain water, which is not a limiting factor in this season. Nonetheless, those farmers would also be interested in the possibility to design suitable cropping systems that include warm season break ASC, in order to optimise the rotations and to achieve the best economic and environmental performances (Butler et al., 2012). However, ASC and especially grass species can take up all the available water in the soil, so there could be a shortage of water for the following cash-crop, particularly during the summer, unless irrigation is used.

In vegetable cropping systems, the break ASC may reduce the risk of $\mathrm{NO}_{3}{ }^{-}$losses principally because they take up mineral $\mathrm{N}$ from the soil especially if it is left bare. This circumstance happens when the vegetable cash crops are not grown because of adverse climatic conditions (i.e. winter in Central and Northern Europe) and/or due to unfavourable market opportunities. The effectiveness of break ASC at lowering the risk of $\mathrm{N}$ losses is remarkable when they are introduced in the period of the year with high rain intensity. During those periods, soil mineral $\mathrm{N}$ not used by the previous crop and/or mineralised during the bare period, is highly potentially 
leachable. Mineral $\mathrm{N}$ taken up by the break ASC and converted into organic matter, is then returned to the cropping system after termination at the end of the ASC cropping cycle. Depending on to the ASC termination techniques (see section 4), the mineralisation rate of plant material may be modulated to synchronise the availability of soil mineral $\mathrm{N}$ with the $\mathrm{N}$ needs of the subsequent cash crop (Canali et al., 2013).

\section{The Role of ASC Genotype and Mixtures of ASC}

A wide range of plant species belonging to different botanical families can be utilised as ASC. However, most of them belong to three families: Graminaceae (grasses), Brassicaceae (brassicas) and Leguminosae (legumes), and only a minor number of species belong to other families (i.e. Polygonaceae or Boraginaceae).

Since plants of the different families show differences in terms of physiology and agronomic characteristics, they have different abilities to provide agro-environmental services. In relation to $\mathrm{N}$, grasses and brassicas have great nutrient requirement, and can take up large quantities of $\mathrm{N}$ during their cropping cycle. If this $\mathrm{N}$ is not available in the soil, their growth is limited. Conversely, the growth of legumes is not limited by $\mathrm{N}$ shortage in the soil since they get the element by biological nitrogen fixation (BNF). It is probably worth to underline that, similarly to the non-legume ASC, legumes also use soil mineral $\mathrm{N}$ to grow if available, instead of BNF processes (Moller et al., 2008; Zhou et al., 2011). Therefore, all ASC could behave as catch crop of excess mineral N, contributing to reducing the risk of $\mathrm{NO}_{3}{ }^{-}$leaching. According to Dabney et al. (2010), the average reduction in $\mathrm{NO}_{3}{ }^{-}$leaching has been identified to be about $70 \%$ for grass or brassica and about $23 \%$ for legume covers. Nitrogen fixed (in the case of legumes) or taken up by the ASC is returned to the system after their termination, when plant tissues incorporated into the soil or used as surface mulch, mineralise and release mineral $\mathrm{N}$. The mineralisation process is controlled by environmental (i.e. soil temperature and moisture) and intrinsic factors related to plant materials characteristics (i.e. lignin and cellulose content, total and soluble $\mathrm{N}$ content, $\mathrm{C} / \mathrm{N}$ ratio; Jensen et al., 2005). In particular, the $\mathrm{C} / \mathrm{N}$ ratio of the plant material, even if considered only an approximate guide to the likely net mineralisation, is often able to provide a valuable prediction of $\mathrm{N}$ mineralisation and can be effectively utilised in the current practice (Canali et al., 2011). In general, legume ASC have, at termination, a lower $\mathrm{C} / \mathrm{N}$ ratio than the non-legumes crops. Grasses, in particular, have the highest values of this parameter. For this reason, the legume plant materials are generally considered less resistant to mineralisation and release $\mathrm{N}$ in the inorganic form more rapidly than the other crops families.

Mineral $\mathrm{N}$ derived from ASC plant materials is available to subsequent cash crops and the prediction of the mineralisation rate is a key aspect to synchronise it with the following crop needs. Indeed, if mineral $\mathrm{N}$ release is not well synchronised with crop needs, its nutritive efficiency is reduced. Moreover, if adverse environmental conditions (i.e., heavy rainfall) occur after ASC termination, the nitric component of the mineralised $\mathrm{N}$ may also be leached (Neeteson et al., 2003). However, $\mathrm{N}$ mineralisation from different organic sources can be opportunely managed if a mixture of residues with variable quality is used, including low $\mathrm{N}$ (high $\mathrm{C} / \mathrm{N}$ ratio, as grasses tissue) and high N (low C/N ratio, as legume tissue) plant materials (Sikora \& Enkiri, 2000; Nyiraneza \& Snapp, 2007). Therefore, the selection of different ASC species and families, because of their different properties and potential mineralisation rate, is an effective tool to manage $\mathrm{N}$ nutrition and the risk of $\mathrm{NO}_{3}{ }^{-}$leaching.

Farmers can decide to seed pure (100\%) legume ASC if high amounts of $\mathrm{N}$ are needed in a short term (i.e. nutrition of high demand vegetable crops) or, conversely, they may seed pure grasses in case of low $\mathrm{N}$ requirement of the next crop and/or, in climatic conditions with high potential risk of $\mathrm{NO}_{3}{ }^{-}$leaching. Moreover, sowing a combination (a mixture) of different proportions (i.e 50/50 or 30/70) of legume and non-legume ASC can determine a range of intermediate scenarios, useful for "fine-tuning" $\mathrm{N}$ dynamic in the soil-plant system (Tosti et al., 2012).

\section{ASC Management Strategies}

\subsection{Living Mulches Management}

As far as the management of LM is concerned, recent scientific literature reports emerging evidences of the influence of several factors on the effectiveness of this technique in providing agro-ecosystem services, in particular modulating $\mathrm{NO}_{3}{ }^{-}$leaching risks. One of these factors is the time of sowing of $\mathrm{LM}$ in respect to the transplanting of the associated cash crop (Adamczewska-Sowińska \& Kołota, 2010). In addition, differences in term of soil mineral $\mathrm{N}$ content and potentially leachable soil $\mathrm{NO}_{3}{ }^{-}$have been observed between $\mathrm{LM}$ substitutive (reduction of cash crop plant density to leave room to LM) and additional design (same crop plant density), and these differences have been attributed to the different $\mathrm{N}$ uptake ability of the LM and the cash crop (Canali et al., 2014; Kristensen et al., 2014). 


\subsection{Break Crops: Green Manure vs Roller Crimper Technology}

ASC need to be terminated prior to the subsequent cash crop planting in order to provide their services to the system and avoid competition. The phenological stage of the crop, the time and method of termination represent crucial management factors, especially in vegetable cropping systems where complex rotations and peculiar soil/plant interactions are in place.

The traditional, and most widespread, technique used to terminate the cropping cycle of the ASC is the incorporation as green manure into the soil by tillage (i.e. plough and/or rotary tiller) (Watson et al., 2002). However, since tillage is an energy and labour consuming and soil disturbing operation, in recent years, systems that use no/reduced tillage have received increasing interest. In this perspective, the rolling crimper technology, which terminates ASC by flattening, represents a promising choice (Mäder \& Berner, 2012). The technique consists of one or two passages of the roller crimper, thus leaving a thick mulch layer into which the next crop is sown or transplanted (Teasdale et al., 2012). The roller crimper is comprised of a steel cylinder (about $41-51 \mathrm{~cm}$ diameter) with steel blades welded perpendicular to the cylinder in a chevron pattern. Prior to ASC termination, the cylinder is filled with water to provide an additional weight to aid in mechanical termination. Accordingly, due to the formation of this natural mulch on the soil surface, derived from the ASC plant materials, the potential capability of the roller crimping technology to control weeds, reduce soil erosion, maintain or increase soil organic matter content, as well as reduce labour use and fossil fuel energy consumption, has been acknowledged (cfr. Special Issue in Renewable Agriculture and Food Systems, 2012). In addition, evidences of the potential of the roller crimper technology to provide vegetable cropping systems resistance to pathogen and pest attacks are emerging (Bryant et al., 2013). Furthermore, the roller crimper technology has been recently investigated as a potential technique to mitigate $\mathrm{NO}_{3}^{-}$leaching risk in vegetables production (Montemurro et al., 2013).

When an ASC is terminated by green manuring, its entire belowground and aboveground soil biomass is incorporated into the soil. According to the biomass amount and the $\mathrm{N}$ content of the plant tissue, it is likely that 50 to $200 \mathrm{~kg} \mathrm{ha}^{-1}$ of organic $\mathrm{N}$, ready to be mineralised, are incorporated into the soil. Depending on the characteristic of the plant biomass (i.e. $\mathrm{C} / \mathrm{N}$ ratio), and soil moisture and temperature, mineralisation rates vary greatly, up to very high values in favourable conditions. Indeed, in the case of break ASC green manure in spring or in early autumn, large quantities of mineral $\mathrm{N}$ may be rapidly released in the soil. If the subsequent cash crop is not ready to take up the mineral $\mathrm{N}$ (i.e. not yet in the fast growing phenological phase), this mineral $\mathrm{N}$ is potentially leachable and/or can be subjected to re-immobilisation processes in the soil, contributing in a limited extent to the cash crop $\mathrm{N}$ nutrition. On the other hand, when the break ASC is terminated by the roller crimper, the soil is no or minimally tilled and the ASC aboveground biomass is not incorporated into the soil. In these conditions, the mineralisation of the organic matter, of the ASC plant material, occurs in the soil-mulch interface, and the mineral $\mathrm{N}$ release may proceed slower than in the green manure (Parr et al., 2014), due to the root biomass which may comprise as much as $12 \%$ of crop biomass amounts (Montemurro et al., 2013).

\section{Organic No-Till With Roller Crimper: Case Studies in Organic Vegetables}

Recent studies have assessed the effectiveness of conservative ASC management in providing ecosystem services and sustaining crop production for different organic vegetables under Mediterranean conditions. In particular, in this section, three case studies on applications of no-till with roller crimper are briefly described for tomato, zucchini and melon crops.

\subsection{Effect of Termination of Hairy Vetch as ASC Preceding Organic Tomato}

A two-year field experiment was performed at the MOVE (MOnsampolo VEgetables) organic long-term experiment (Campanelli \& Canali, 2012) of the CRA-Research Unit for Vegetable Crops, located at Monsampolo del Tronto (Central Italy). Hairy vetch (Vicia villosa Roth var. Minnie) was grown as break autumn-winter ASC followed by tomato (Solanum lycopersicum L. cv. SAAB CRA) for fresh consumption. The following treatments were compared on three large plots: i) roller crimper (cover crop flattened by a roller-crimper - RC); ii) green manure (cover crop biomass chopped and plowed into the soil - GM); in comparison with iii) fallow artificially mulched with Mater-Bi ${ }^{\circledR}$ bioplastic (AM).

No significant differences were found in tomato marketable crop production in RC with respect to GM and AM, suggesting that tomato was suitable to be grown after termination of the ASC by roller crimping (Table 1). This result was supported by the lowest unmarketable yield obtained in RC treatment, which was lower by about $42 \%$ than the average of GM and AM treatments, confirming Campiglia et al. (2011) findings. The obtained results suggest that flattened vetch may have promoted a gradual release of $\mathrm{N}$ to tomato during the cropping cycle, matching the needs of the crop, thus improving its nutritional status (Montemurro et al., 2013). No significant differences were found among treatments for fruit weight and ${ }^{\circ}$ Brix, therefore, both yield and quality indicate 
that ASC management that includes leguminous crops could enable the reduction of off-farm $\mathrm{N}$ fertilizers application (Doane et al., 2009).

Table 1. Effect of ASC management on marketable and unmarketable tomato production

\begin{tabular}{|c|c|c|c|c|c|c|c|c|c|c|c|c|}
\hline \multirow[b]{2}{*}{ Treatments } & \multicolumn{8}{|c|}{ Marketable yield } & \multicolumn{4}{|c|}{ Unmarketable yield } \\
\hline & $\begin{array}{l}\text { Fruits } \\
\text { plant }^{-1}\end{array}$ & $\begin{array}{l}\text { Std. } \\
\text { dev. }\end{array}$ & $\mathrm{tha}^{-1}$ & $\begin{array}{l}\text { Std. } \\
\text { dev. }\end{array}$ & $\begin{array}{l}\text { g } \\
\text { fruit }^{-1}\end{array}$ & $\begin{array}{l}\text { Std. } \\
\text { dev. }\end{array}$ & $\begin{array}{l}\circ \\
\text { Brix }\end{array}$ & $\begin{array}{l}\text { Std. } \\
\text { dev. }\end{array}$ & $\begin{array}{l}\text { Fruits } \\
\text { plant }^{-1}\end{array}$ & $\begin{array}{l}\text { Std. } \\
\text { dev. }\end{array}$ & $\mathrm{tha}^{-1}$ & $\begin{array}{l}\text { Std. } \\
\text { dev. }\end{array}$ \\
\hline $\mathrm{RC}$ & $11.3 \mathrm{a}$ & 0.64 & $55.7 \mathrm{a}$ & 2.72 & $224 \mathrm{a}$ & 13.6 & $5.13 \mathrm{a}$ & 0.28 & $1.25 \mathrm{a}$ & 0.07 & $4.30 \mathrm{~b}$ & 0.24 \\
\hline GM & $10.6 \mathrm{a}$ & 0.72 & $52.9 \mathrm{a}$ & 2.64 & $229 \mathrm{a}$ & 13.2 & $5.36 \mathrm{a}$ & 0.34 & $2.04 \mathrm{a}$ & 0.13 & $6.86 \mathrm{a}$ & 0.37 \\
\hline AM & $10.2 \mathrm{a}$ & 0.56 & $44.4 \mathrm{a}$ & 2.44 & $200 \mathrm{a}$ & 14.0 & $5.38 \mathrm{a}$ & 0.29 & $2.33 \mathrm{a}$ & 0.13 & $7.87 \mathrm{a}$ & 0.36 \\
\hline
\end{tabular}

Note: $\mathrm{RC}=$ roller crimper; $\mathrm{GM}=$ green manure; $\mathrm{AM}=$ fallow artificially mulched with Mater $\mathrm{Bi}$. The mean values in each column followed by a different letter are significantly different according to Fisher LSD at the $\mathrm{P} \leq 0.05$ probability level.

\subsection{Roller Crimper Technology for Weed Control in Organic Zucchini}

A two-year field experiment was carried out in the same site of the previous experiment. Transplanted zucchini (Cucurbita pepo L.) was grown to compare the effect of ASC (barley, Hordeum vulgare L.) management strategies (no cover crop control - CT; green manured barley - GM; flattened barley mulch obtained by roller crimper technique - RC) on crop agronomic performace. Energy consumption and total energy cost were also evaluated, recording number and type of mechanical tillage operations for each treatment.

Zucchini cultivated by RC technique yielded $69 \%$ more than the zucchini preceded by the GM and similarly to the CT (Table 2). Moreover, the highly significant effect of ASC management for the zucchini total yield and the crop residues suggested the effectiveness of the mulch obtained by the RC in controlling weeds, although other influencing factors cannot be excluded. Weed above ground biomass was 22 and $91 \%$ lower than the CT, in the GM and in the RC treatments, respectively. High level of weed control was likely due to a direct effect of the barley mulch layer, which formed a barrier able to intercept solar radiation, thus reducing the stimulation for weed germination and physically impeding the weed growth (Altieri et al., 2011). Moreover, the conservative ASC termination reduced by $56 \%$ nonrenewable fossil energy consumption for tillage operations (data not shown) in comparison to GM, which is the most widely used system by organic farmers to manage cover crops. Results demonstrated that adoption of the RC could enhance the sustainability of organically managed vegetable cropping systems.

Table 2. Effect of ASC management on zucchini total and marketable yield, zucchini above ground crop residues biomass and weed biomass

\begin{tabular}{lllllllll}
\hline \multirow{2}{*}{ Treatments } & $\begin{array}{l}\text { Zucchini } \\
\text { total } \\
\text { yield }\end{array}$ & $\begin{array}{l}\text { Std. } \\
\text { dev. }\end{array}$ & $\begin{array}{l}\text { Marketable } \\
\text { yield }\end{array}$ & $\begin{array}{l}\text { Std. } \\
\text { dev. }\end{array}$ & $\begin{array}{l}\text { Zucchini } \\
\text { crop } \\
\text { residues }\end{array}$ & $\begin{array}{l}\text { Std. } \\
\text { dev. }\end{array}$ & $\begin{array}{l}\text { Weed above } \\
\text { ground } \\
\text { biomass }\end{array}$ & $\begin{array}{l}\text { Std. } \\
\text { dev. }\end{array}$ \\
\cline { 2 - 9 } & $\mathrm{tha}^{-1}$ & & $\mathrm{~kg} \mathrm{plant}^{-1}$ & & $\mathrm{t} \mathrm{ha}^{-1}$ & & $\mathrm{t} \mathrm{ha}^{-1}$ & \\
\hline $\mathrm{CT}$ & $18.5 \mathrm{ab}$ & 1.03 & $2.7 \mathrm{a}$ & 0.16 & $8.7 \mathrm{a}$ & 0.51 & $31.9 \mathrm{a}$ & 1.94 \\
$\mathrm{GM}$ & $13.7 \mathrm{~b}$ & 0.87 & $1.7 \mathrm{~b}$ & 0.11 & $5.1 \mathrm{~b}$ & 0.34 & $24.9 \mathrm{~b}$ & 1.39 \\
$\mathrm{RC}$ & $23.1 \mathrm{a}$ & 1.36 & $2.6 \mathrm{a}$ & 0.15 & $9.9 \mathrm{a}$ & 0.56 & $3.5 \mathrm{c}$ & 0.23 \\
& $* *$ & & $* * *$ & & $* *$ & & $* * *$ & \\
\hline
\end{tabular}

Note: $\mathrm{CT}=$ control; $\mathrm{GM}=$ green manure; $\mathrm{RC}=$ roller crimper. The mean values in each column followed by a different letter are significantly different according to DMRT at the reported probability level. ***, P $\leq 0.001$; **, $\mathrm{P} \leq 0.01$. 


\subsection{Combining ASC Managements and Organic Fertilization Strategies in Organic Melon}

The suitability of different termination strategies of ASC (vetch, Vicia sativa L. 'Buza') was studied on melon crop (Cucumis melo L. var. Emerson F1) at Metaponto (MT), in southern Italy, in a field located at the experimental farm of the CRA-Research Unit for Cropping Systems in Dry Environments. The following treatments were tested: i) fallow (FA), without ASC; ii) green manure - GM, vetch chopped and plowed; and iii) roller-crimper - RC, vetch flattened by a roller-crimper, in combination with organic fertilizers (allowed in organic farming) application: i) commercial humified fertilizer - CHF; ii) anaerobic digestate - AD; iii) composted municipal solid wastes - MSW, as compared to iv) unfertilized control - NO.

Total yield was similar among treatments. In NO the RC produced significantly lower total yield than GM and FA (by 46 and 33\%, respectively) (Table 3). This might have been the result of less N supplied by the ASC with this strategy, because only the root biomass was totally available for mineralization from the beginning of the melon cropping cycle, while the above soil biomass mineralized in a slow process at the mulch-soil interface. No substantial differences were found in all the other ASC management by fertilizer interactions, confirming the suitability of matching these strategies (Rizk, 2012) also on melon crop.

Table 3. Effect of ASC management and fertilizer treatments on melon total yield $\left(\mathrm{t} \mathrm{ha}^{-1}\right)$ and marketable fruit weight $(\mathrm{kg})$

\begin{tabular}{|c|c|c|c|c|c|c|c|c|c|c|c|c|}
\hline \multicolumn{6}{|c|}{ Total yield } & \multicolumn{7}{|c|}{ Average marketable fruit wt } \\
\hline & FA & GM & $\mathrm{RC}$ & CHF AD & MSW N0 & FA & GM & $\mathrm{RC}$ & $\mathrm{CHF}$ & $\mathrm{AD}$ & MSW & No \\
\hline & $56.9 \mathrm{~b}$ & $52.8 \mathrm{bc}$ & $48.1 \mathrm{bc}$ & $65.3 \mathrm{a} 50.7 \mathrm{bc}$ & $45.8 \mathrm{c} \quad 48.6 \mathrm{bc}$ & $2.57 \mathrm{ab}$ & $2.49 \mathrm{ab}$ & $2.57 \mathrm{ab}$ & $2.96 \mathrm{a}$ & $2.61 \mathrm{ab}$ & $2.28 \mathrm{~b}$ & $2.33 b$ \\
\hline CHF & $74.7 \mathrm{a}$ & $60.1 \mathrm{a}$ & $61.3 \mathrm{a}$ & & & $3.48 \mathrm{a}$ & $3.09 a$ & $2.32 \mathrm{a}$ & & & & \\
\hline $\mathrm{AD}$ & $51.1 \mathrm{a}$ & $49.5 \mathrm{a}$ & $51.5 \mathrm{a}$ & & & $2.44 \mathrm{a}$ & $2.70 \mathrm{a}$ & $2.69 a$ & & & & \\
\hline MSW & $51.8 \mathrm{a}$ & $39.5 \mathrm{a}$ & $45.9 \mathrm{a}$ & & & $2.29 \mathrm{a}$ & $2.12 \mathrm{a}$ & $2.45 \mathrm{a}$ & & & & \\
\hline $\mathrm{NO}$ & $50.1 \mathrm{a}$ & $62.1 \mathrm{a}$ & $33.5 \mathrm{~b}$ & & & $2.06 \mathrm{a}$ & $2.09 \mathrm{a}$ & $2.85 \mathrm{a}$ & & & & \\
\hline
\end{tabular}

Note: $\mathrm{FA}=$ fallow; $\mathrm{GM}=$ green manure; $\mathrm{RC}=$ roller crimper; $\mathrm{CHF}=$ commercial humified fertilizer; $\mathrm{AD}=$ anaerobic digestate; $\mathrm{MSW}=$ composted municipal solid wastes; $\mathrm{NO}=$ unfertilized control. Means of cover crop managements and organic fertilizer treatments followed by different letters within rows are significantly different according to DMRT $(\mathrm{P}<0.05)$.

\section{Conclusion and Research Needs}

Despite the wide acknowledgement of the contribution of the Agro-ecological Service Crops to sustain agricultural production and to promote environmental protection by a wide range of mechanisms, their diffusion within organic and sustainable low input cropping systems is still limited. This is due to low awareness on the selection of the most appropriate genotypes and termination strategies (i.e. technology, time of termination, etc.). Accordingly, to further empower the use of ASC in a wide range of agro-climatic conditions, research activities specific to various areas should be encouraged.

Indeed, with specific reference to the European Mediterranean eco-climatic zones, the cultivation of warm season break ASC is limited by several constrains (i.e. lack of knowledge about the best performing genotypes, slow growth, high water needs) and, in the last decades, research activities to overcome these problems has been limited. Consequently, nowadays Southern Europe (organic) vegetable farmers have no or very limited feasible options, hence reducing or disabling the possibility to design more resilient cropping systems. Accordingly, research activities aimed to verify the effectiveness of warm season ASC to contribute to build up soil N fertility as well as to reduce $\mathrm{NO}_{3}^{-}$leaching at the beginning of the leaching season (autumn) should be highly encouraged.

For alternative termination strategies, the roller crimper technology to terminate by flattening ASC has been successfully tested in few cropping systems and eco-zone across Europe. However, the experiences acquired so far and the current scientific literature have identified some constrains in the use of this technology. These include: (i) the production of proper amount of cover crop biomass before rolling, (ii) the cover crops re-growth during the subsequent main crop cycle, (iii) nitrogen $(\mathrm{N})$ immobilisation and the difficulty in applying fertilisers 
in the ASC residues forming the mulch, and (iv) low quality of the transplanting or sowing bed preparation. These constrains could further limit success of the roller crimper technology in the Continental and Northern Oceanic eco-climatic area of Europe, where the cash cropping season (spring - summer) is short and soil temperatures remain low for a longer period. Moreover, the application of the roller crimper technology could be limited in vegetable cropping systems because of the low competitive ability of vegetables relative to other species (i.e. cover crops and weeds) and their high nutrients demand (Mortensen et al., 2000). Therefore, further studies are needed to test the effectinveness of the technology in other parts or Europe. In detail, additional studies should be aimed to understand the dynamic of $\mathrm{N}$ mineralisation in the soil-mulch interface and the synchronisation of release of mineral $\mathrm{N}$ with the subsequent cash crop $\mathrm{N}$ requirements.

Moreover, more effective machinery to perform an extremely reduced tillage system relying on the concept of "in-line tillage" to implement the vegetable transplanting and use of the roller crimper should be further developed. Such a machine is being developed by slightly modifying a roller crimper (Canali et al., 2013). In particular, a sharp vertical disk and a coulter (or chisel) were installed in-line at both the front and rear of the roller. This prototype machine allows to flatten the cover crops and to obtain a 0.2 to $0.3-\mathrm{m}$ deep and few centimeters wide transplanting furrow in a single pass.

Lastly, in order to give guidance to farmers and technisscisans among the different available options regarding the introduction of (mixtures of) ASC into vegetable cropping systems, the choice of the suitable ASC genotypes and the proper terminations strategies to be adopted, ready to use Decision Supporting Systems (DSS) should be developed, tested and disseminated to farmers.

\section{References}

Altieri, M. A., Lana, M. A., Bittencourt, H. V., Kieling, A. S., Comin, J. J., \& Lovato, P. E. (2011). Enhancing crop productivity via weed suppression in organic no-till cropping systems in Santa Catarina, Brasil. $J$. Sustain. Agr, 35, 855-869. http://dx.doi.org/10.1080/10440046.2011.588998

Adamczewska-Sowińska, K., \& Kołota, E. (2010). Yielding and nutritive value of field cultivated eggplant with the use of living and synthetic mulches. Acta Sci. Pol.- Hortoru, 9(3), 191-199.

Bàrberi, P. (2002). Weed management in organic agriculture: Are we addressing the right issues? Weed Res, 42, 177-193. http://dx.doi.org/10.1046/j.1365-3180.2002.00277.x

Båth, B., Kristensen, H. L., \& Thorup-Kristensen, K. (2008). Root pruning reduces root competition and increases crop growth in a living mulch cropping system. J. Plant Interactions, 3, 211-221. http://dx.doi.org/10.1080/17429140801975161

Bryant, A., Brainard, D. C., Haramoto, E. R., \& Szendrei, Z. (2013). Cover crop mulch and weed management influence arthropod communities in strip-tilled cabbage. Environ. Entomol, 42, 293-306. http://dx.doi.org/10.1603/EN12192

Butler, D., Rosskopf, E., Kokalis-Burelle, N., Albano, J., Muramoto, J., \& Shennan, C. (2012). Exploring warm-season cover crops as carbon sources for anaerobic soil disinfestation (ASD). Plant Soil, 355, 149-165. http://dx.doi.org/10.1007/s11104-011-1088-0

Campanelli, G., \& Canali, S. (2012). Crop production and environmental effects in conventional and organic vegetable farming systems: the case of a long term experiment in Mediterranean conditions (Central Italy). J. Sustain. Agr, 36(6), 599-619. http://dx.doi.org/10.1080/10440046.2011.646351

Campiglia, E., Mancinelli, R., \& Radicetti, E. (2011). Influence of no-tillage and organic mulching on tomato (Solanum lycopersicum L.) production and nitrogen use in the Mediterranean environment of central Italy. Sci. Hortic-Amsterdam, 130, 588-598. http://dx.doi.org/10.1016/j.scienta.2011.08.012

Canali, S. (2013). Ecological services providing crops (Escs) in organic vegetable production systems. Retrieved from http://orgprints.org/22570/

Canali, S., Campanelli, G., Bavec, F., von Fragstein, P., Leteo, F., Jocop, M., \& Kristensen, H. L. (2014). Do living mulch based vegetable cropping systems yield similarly to the sole ones? Build. Org. Bridges, 1, 167-170.

Canali, S., Campanelli, G., Ciaccia, C., Leteo, F., Testani, E., \& Montemurro, F. (2013). Conservation tillage strategy based on the roller crimper technology for weed control in Mediterranean vegetable organic cropping systems. Eur. J. Agron, 50, 11-18. http://dx.doi.org/10.1016/j.eja.2013.05.001

Canali, S., Di Bartolomeo, E., Tittarelli, F., Montemurro, F., Verrastro, V., \& Ferri, D. (2011). Comparison of 
different laboratory incubation procedures to evaluate nitrogen mineralization in soils amended with aerobic and anaerobic stabilized organic materials. J. Food Agric. Environ, 9, 540-546.

Chase, C. A., \& Mbuya, O. S. (2008). Greater interference from living mulches than weeds in organic broccoli production. Weed Technol, 22(2), 280-285. http://dx.doi.org/10.1614/WT-07-119.1

Dabney, S. M., Delgado, J. A., Meisinger, J. J., Schomberg, H. H., Liebig, M. A., Kaspar, T., ... Reeves, W. (2010). Using cover crops and cropping cystems for nitrogen management. chapter 9. In J. A. Delgado \& R. F. Follett (Eds.), Advances in nitrogen management for water quality. Ankeny, IA: Soil and Water Conservation Society.

Doane, T. A., Horwath, W. R., Mitchell, J. P., Jackson, J., Miyao, G., \& Brittan, K. (2009). Nitrogen supply from fertilizer and legume cover crop in the transition to notillage for irrigated row crops. Nutr. Cycl. Agroecosystems, 85, 253-262. http://dx.doi.org/10.1007/s10705-009-9264-9

Gomiero, T., Pimentel, D., \& Paoletti, M. G. (2008). Energy and environmental issues in organic and conventional agriculture. Cr. Rev. Plant Sci, 27, 239-254. http://dx.doi.org/10.1080/07352680802225456

Hayden, Z. D., Brainard, D. C., Henshaw, B., \& Ngouajio, M. (2012). Winter annual weed suppression in rye-vetch cover crop mixtures. Weed Technol, 26, 818-825. http://dx.doi.org/10.1614/WT-D-12-00084.1

Hiltbrunner, J., Liedgens, M., Bloch, L., Stamp, P., \& Streit, B. (2007). Legume cover crops as living mulches for winter wheat: Components of biomass and the control of weeds. Eur. J. Agron, 26, 21-29. http://dx.doi.org/10.1016/j.eja.2006.08.002

Hooks, C. R., \& Johnson, M. W. (2004). Using undersown clovers as living mulches: Effects on yields, lepidopterous pest infestations, and spider densities in a hawaiian broccoli agroecosystem. Int. J. Pest Manage, 50, 115-120. http://dx.doi.org/10.1080/09670870410001663462

Jensen, L., Salo, T., Palmason, F., Breland, T., Henriksen, T., Stenberg, B., \& Esala, M. (2005). Influence of biochemical quality on $\mathrm{C}$ and $\mathrm{N}$ mineralisation from a broad variety of plant materials in soil. Plant Soil, 273, 307-326. http://dx.doi.org/10.1007/s11104-004-8128-y

Kremen, C., \& Miles, A. (2012). Ecosystem services in biologically diversified versus conventional farming systems: benefits, externalities, and trade-offs. Ecol. Soc, 17, Art. 40. http://dx.doi.org/10.5751/ES-05035-170440

Kristensen, H. L., Campanelli, G., Bavec, F., von Fragstein und Niemsdorff, P., Canali, S., \& Tittarelli, F. (2014). Effect of an in-season living mulch on leaching of inorganic nitrogen in cauliflower (Brassica Oleracea L. Var. Botrytis) cropping in Slovenia, Germany and Denmark. Build. Org. Bridges, 1, 199-202.

Kristensen, H. L., \& Thorup-Kristensen, K. (2004). Uptake of $15 \mathrm{~N}$ labeled nitrate by root systems of sweet corn, carrot and white cabbage from 0.2-2.5 meters depth. Plant Soil, 265, 93-100. http://dx.doi.org/10.1007/s11104-005-0696-y

Mäder, P., \& Berner, A. (2012). Development of reduced tillage systems in organic farming in Europe. Renew. Agr. Food Syst, 27, 7-11. http://dx.doi.org/10.1017/S1742170511000470

Marshall, E. J., \& Moonen, A. (2002). Field margins in northern Europe: their functions and interactions with agriculture. Agr. Ecosyst.Environ, 89, 5-21. http://dx.doi.org/10.1016/S0167-8809(01)00315-2

Masiunas, J. B. (1998). Production of vegetables using cover crop and living mulches - a review. J. .Veg. Crop Prod, 4, 11-31.

Mazzoncini, M., Sapkota, T. B., Bàrberi, P., Antichi, D., \& Risaliti, R. (2011). Long-term effect of tillage, nitrogen fertilization and cover crops on soil organic carbon and total nitrogen content. Soil Till. Res, 114, 165-174. http://dx.doi.org/10.1016/j.still.2011.05.001

Möller, K., Stinner, W., \& Leithold, G. (2008). Growth, composition, biological N2 fixation and nutrient uptake of a leguminous cover crop mixture and the effect of their removal on field nitrogen balances and nitrate leaching risk. Nutr. Cycl. Agroecosystems, 82, 233-249. http://dx.doi.org/10.1007/s10705-008-9182-2

Montemurro, F., Fiore, A., Campanelli, G., Tittarelli, F., Ledda, L., \& Canali, S. (2013). Organic fertilization, green manure, and vetch mulch to improve organic zucchini yield and quality. HortScience, 48, 1027-1033.

Mortensen, D. A., Bastiaans, L., \& Sattin, M. (2000). The role of ecology in the development of weed management systems: an outlook. Weed Res, 40, 49-62. http://dx.doi.org/10.1046/j.1365-3180.2000.00174.x 
Neeteson, J. J., Langeveld, J. W. A., Smit, A. L., \& De Haan, J. J. (2003). Nutrient balances in field vegetable production systems. Acta Horticulturae, 627, 13-23.

Nyiraneza, J., \& Snapp, S. (2007). Integrated management of inorganic and organic nitrogen and efficiency in potato systems. Soil Sci. Soc. Am. J, 71, 1508-1515. http://dx.doi.org/10.2136/sssaj2006.0261

Parr, M., Grossman, J. M., Reberg-Horton, S. C., Brinton, C., \& Crozier, C. (2011). Nitrogen delivery from legume cover crops in no-till organic corn production. Agron. J, 103, 1578-1590. http://dx.doi.org/10.2134/agronj2011.0007

Parr, M., Grossman, J. M., Reberg-Horton, S. C., Brinton, C., \& Crozier, C. (2014). Roller crimper termination for legume cover crops in North Carolina: impacts on nutrient availability to a succeeding corn crop. Commun. Soil Sci. Plan, 45, 1106-1119. http://dx.doi.org/10.1080/00103624.2013.867061

Patkowska, E., \& Konopin'ski, M. (2013). Harmfulness of soil-borne fungi towards root chicory (Cichorium intybus L. var. sativum Bisch.) cultivated with the use of cover crops. Acta Sci. Pol.- Hortoru, 12, 3-18.

Rizk, M. H. (2012). Effect of some legume cover crops and organic fertilizer on petiole nutrient content, productivity and fruit composition of 'Thompson seedless' grapevines. Acta Horticulturae, 933, 381-387.

Sanz-Cobena, A., García-Marco, S., Quemada, M., Gabriel, J. L., Almendros, P., \& Vallejo, A. (2014). Do cover crops enhance $\mathrm{N}_{2} \mathrm{O}, \mathrm{CO}_{2}$ or $\mathrm{CH}_{4}$ emissions from soil in Mediterranean arable systems? Sci. Total Environ, 466/467, 164-174. http://dx.doi.org/10.1016/j.scitotenv.2013.07.023

Sikora, L. J., \& Enkiri, N. K. (2000). Efficiency of compost-fertilizers blends compared with fertilizer alone. Soil Sci, 165, 444-451. http://dx.doi.org/10.1097/00010694-200005000-00009

Swenson, J. A., Walters, S. A., \& Chong, S.-K. (2004). Influence of tillage and mulching systems on soil water and tomato fruit yield and quality. Journal Veg. Crop Prod, 10, 81-95. http://dx.doi.org/10.1300/J068v10n01_09

Teasdale, J. R., Mirsky, S. B., Spargo, J. T., Cavigelli, M. A., \& Maul, J. E. (2012). Reduced-tillage organic corn production in a hairy vetch cover crop. Agron. J, 104, 621-628. http://dx.doi.org/10.2134/agronj2011.0317

Thériault, F., Stewart, K. A., \& Seguin, P. (2009a). Incidence of Pieris rapae in organic broccoli grown with living mulches under floating row cover. Int. J. Veg. Science, 15, 218-225. http://dx.doi.org/10.1080/19315260902727809

Thériault, F., Stewart, K. A., \& Seguin, P. (2009b). Use of perennial legumes living mulches and green manures for the fertilization of organic broccoli. Int. J. Veg. Science, 15, 142-157. http://dx.doi.org/10.1080/19315260802598896

Thorup-Kristensen, K., Dresbøll, D. B., \& Kristensen, H. L. (2012). Crop yield, root growth, and nutrient dynamics in a conventional and three organic cropping systems with different levels of external inputs and $\mathrm{N}$ re-cycling through fertility building crops. Eur. J. Agron, 37, 66-82. http://dx.doi.org/10.1016/j.eja.2011.11.004

Tilman, D., Cassman, K. G., Matson, P. A., Naylor, R., \& Polasky, S. (2002). Agricultural sustainability and intensive production practices. Nature, 418, 671-677. http://dx.doi.org/10.1038/nature01014

Tosti, G., Benincasa, P., Farneselli, M., Pace, R., Tei, F., Guiducci, M., \& Thorup-Kristensen, K. (2012). Green manuring effect of pure and mixed barley - hairy vetch winter cover crops on maize and processing tomato N nutrition. Europ. J. Agronomy, 43, 136-146. http://dx.doi.org/10.1016/j.eja.2012.06.004

Vanek, S., Wien, H. C., \& Rangarajan, A. (2005). Time of interseeding of lana vetch and winter rye cover strips determines competitive impact on pumpkins grown using organic practices. HortScience, 40, 1716-1722.

Watson, C. A., Atkinson, D., Gosling, P., Jackson, L. R., \& Rayns, F. W. (2002). Managing soil fertility in organic farming systems. Soil Use Manage, 18, 239-247. http://dx.doi.org/10.1079/SUM2002131

Wezel, A., Casagrande, M., Celette, F., Vian, J.-F., Ferrer, A., \& Peigné, J. (2014). Agroecological practices for sustainable agriculture. A review. Agron. Sustain. Dev, 34, 1-20. http://dx.doi.org/10.1007/s13593-013-0180-7

Zhou, X., Liu, X., Rui, Y., Chen, C., Wu, H., \& Xu, Z. (2011). Symbiotic nitrogen fixation and soil N availability under legume crops in an arid environment. $J$. Soils Sediments, 11, 762-770. http://dx.doi.org/10.1007/s11368-011-0353-4 


\section{Copyrights}

Copyright for this article is retained by the author(s), with first publication rights granted to the journal.

This is an open-access article distributed under the terms and conditions of the Creative Commons Attribution license (http://creativecommons.org/licenses/by/3.0/). 